\title{
Investigation and Analysis of Consumption Potential of Clothing Functional Market of Chinese Elderly

\author{
Jun YIN
}

\author{
Wuhan Textile University, Wuhan, 430073, China \\ email: 12408113@qq.com
}

Key word: The Elderly; Functional Clothing; Rigid Demand; Living Quality

\begin{abstract}
The rise of income level in recent years has also brought changes to consumption concept of urban elderly. They begin to pay much attention to their own health and are willing to spend money on the development of physical health and the creation of self-image. Chinese elderly spend about 150 to 350 Yuan every month on clothing and health care products. From the angle of dress designing researchers, our functional dress designing products should combine the psychological and physical need of the elderly and raise the living quality of them. With the advert of next elderly boom, the market potential for functional clothing is huge.
\end{abstract}

\section{Introduction}

With the progress of society and development of science and technology, the extension of average life span leads to the proportion increase of the elderly in society and also the aging of population has become a worldwide problem. In 2015, the number of 60 -year-old people will reach 210,000,000, accounting for $15.5 \%$ of the Chinese population. [1] According to the figure of national aging office, the aging population will come to 248,000,000 in 2020 and the aging level will arrive at $17 \%$. [2] The development of aging society and the sharp increase of aging population indicate that the potential of silver-haired market is increasing unceasingly, which poses challenge to national and social planning and meanwhile creates huge business opportunity.

\section{The Basic situation of Elderly People's Consuming Behavior}

\section{The consumption concept and structure of the elderly}

Through the analysis and interview survey of functional clothing consumption of 400 elderly people over 60 in Wuhan, the author finds that in terms of consumption concept, most of the elderly are rational consumers and they prefer to buy economical goods and won't buy cheap goods that are useless to them. [3] They make appropriate, reasonable and calculated consumption plan in daily life and have great stability.

Chart 1 Investigation result of elderly people's consumption concept

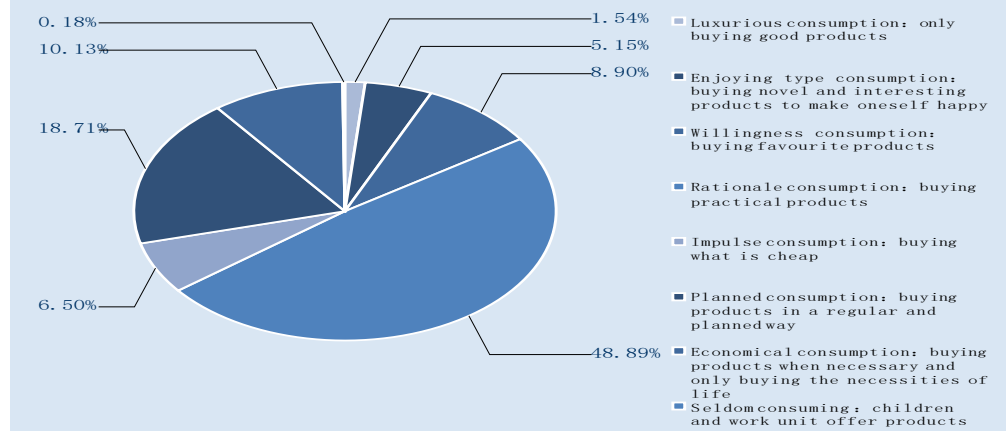

The consumption structure of Chinese elderly has the following characteristics: firstly, food, clothing, housing, transport and other daily necessities are the indispensable consumption items; secondly, because of the declining physical condition, the expense in hiring nursing staff, purchasing health care drugs and so on holds a certain proportion in the consumption; thirdly, influenced by Chinese traditional culture, most of the elderly give economic assistance to their children. 
Chart 2 The consumption structure and ration of the elderly

\begin{tabular}{|c|c|c|c|c|c|c|c|c|c|c|}
\hline & food & utilities & f $o r$ & amus & furnit & travel & clothi & hire & Health & Total number per \\
\hline & & & $\underset{n}{\text { childre }}$ & $\underset{t}{\text { emen }}$ & $\mathrm{u} r \mathrm{e}$ & & & & $\mathrm{c} \mathrm{a} \mathrm{re}$ & $\begin{array}{llll}m & \mathrm{o} & \mathrm{n} & \mathrm{t}\end{array}$ \\
\hline $\begin{array}{c}\text { Percentage } \\
(100 \%)\end{array}$ & 70.69 & 11.64 & 7.62 & 0.2 & 2.74 & 0.27 & 1.42 & 0.23 & 0.23 & 100 \\
\hline
\end{tabular}

\section{The purchasing power of clothing}

In the clothing expense, take the elderly in Wuhan for example. It is found that about $70 \%$ of the elderly have a disbursable sum of over 1000 yuan every month and that their buying cycle is indefinite and that the dominant motive for their consumption is children's company and that $68.37 \%$ of the elderly can accept 100-300 Yuan clothing price in the article "consumption investigation and measures for the clothing consumption of the elderly in Wuhan", which studies the purchasing power of the elderly through a 500-questionnaire survey (recovery of 420) of elderly people over 60. [4]

Chart 3 Investigation of elderly people's purchasing power

\begin{tabular}{|c|c|c|c|c|}
\hline $\begin{array}{l}\text { Investigation } \\
\text { items }\end{array}$ & items & Statistical data & items & Statistical data \\
\hline $\begin{array}{l}\text { Monthly } \\
\text { discretionary } \\
\text { expense }\end{array}$ & $\begin{array}{c}\text { Less than } 1000 \\
\text { yuan }\end{array}$ & $31.6 \%$ & $\begin{array}{c}1000 \text { to } 3000 \\
\text { yuan }\end{array}$ & $60.2 \%$ \\
\hline income & $\begin{array}{c}3000 \text { to } 5000 \\
\text { yuan }\end{array}$ & $7.2 \%$ & $\begin{array}{l}\text { More than } 5000 \\
\text { yuan }\end{array}$ & $1 \%$ \\
\hline \multirow[t]{2}{*}{ Purchasing cycle } & One month & $6.66 \%$ & One quarter & $26.67 \%$ \\
\hline & holiday & $20 \%$ & irregular & $46.67 \%$ \\
\hline \multirow[t]{3}{*}{$\begin{array}{l}\text { Purchasing } \\
\text { motive }\end{array}$} & $\begin{array}{l}\text { Life and work } \\
\text { needs }\end{array}$ & $26.1 \%$ & $\begin{array}{l}\text { Discount and } \\
\text { promotion }\end{array}$ & $13.94 \%$ \\
\hline & $\begin{array}{l}\text { Accepting } \\
\text { promoted } \\
\text { products }\end{array}$ & $6.34 \%$ & $\begin{array}{l}\text { Buying products } \\
\text { in children's } \\
\text { company }\end{array}$ & $51.81 \%$ \\
\hline & $\begin{array}{c}\text { Presenting to } \\
\text { others }\end{array}$ & $1.81 \%$ & & \\
\hline \multirow[t]{3}{*}{ Acceptable price } & $\begin{array}{l}\text { Less than } 100 \\
\text { yuan }\end{array}$ & $6.14 \%$ & 100 to 300 yuan & $68.37 \%$ \\
\hline & 300 to 600 yuan & $13.02 \%$ & 600 to 1000 yuan & $11.21 \%$ \\
\hline & $\begin{array}{c}\text { More than } 1000 \\
\text { yuan }\end{array}$ & $1.26 \%$ & & \\
\hline
\end{tabular}

Based on the two points mentioned above, the purchasing power of Chinese elderly is fine and their monthly expense in clothing and health care product is 150 to 350 yuan. With the development of market economy, traditional seller market will gradually give way to demand-oriented buyer market. Economy development mainly depends on market demand and the consumer demand comes first in market demand.

\section{Analysis of the Consuming Behavior of Functional Clothing of the Elderly}

$\mathrm{J}$-Blaise holds that consuming behavior is "an active interaction effect between emotion and cognition, behavior, as well as people's communication with their life".

Elderly people's consumption demand for functional clothing

The demand of contemporary elderly people is the foundation for aging industry development; therefore, the logical start of studying the aging industry development should be elderly people's demand. Based on the consumption form, division of elderly people's demand, which is basically the same as that of any other age group, can be classified into four types: material consumption, cultural consumption, health care consumption and service consumption. The material consumption of the elderly includes food, clothing, housing, transport and other basic necessities of life; cultural consumption of the elderly includes the need for culture, art, sports, entertainment, education and so on; service consumption of the elderly includes nursing service, health and disease advisory service, 
the household management service and so on. [5]The physical and health condition of the elderly, especially the very elderly who are worse than the young old in consciousness and movement coordination, decline gradually with the aging process, making elderly people's consumption remarkable mainly in the health care expense and service expense. Therefore, the old population has more need for perfect health care and care service than the young population. But in another investigation, it is also discovered that most of the disabled elderly are unwilling to employ nursing workers to take care of themselves and neither are they willing to trouble other people. Many of the disabled elderly are afraid to add trouble to other people, so they just depend on themselves as much as possible. However, in the current design, there is little functional product which can help the elderly to solve the everyday problems. For clothing, which has the closest contact with everyday life, there are less such products and a few products like knee protector, wrister protector or other similar products, are not obvious in function. In 2015, the design work ranking first in the US Young Designer Award is the fashionable clothing for disabled people in the wheelchair. It not only has strong function and convenience in wearing, but also has fashionable appearance. In recent years, we can find that many design works return to "people-oriented" style and start from the demand and "design for value". From the angle of dress designing researchers, our functional dress designing product should combine the psychological and physical need of the elderly and solve their problems and raise their living quality.

Influencing factors of elderly people's functional clothing consumption

In "An investigation of the functional clothing consumption of the elderly in Wuhan ", the author sets 10 questions about elderly people's standard of selecting clothes and adopts a five-level scale (absolutely no, no, general, yes, truly yes). Through the frequency analysis, the author concludes that basic factor, quality factor, function factor, service factor, price factor and brand factor are the factors that influence elderly people's selection of functional clothing.

Chart 4 Influencing factors of elderly people's selecting functional clothing

\begin{tabular}{|c|c|c|c|c|}
\hline \multicolumn{2}{|c|}{ Influencing factors } & necessary & unnecessary & indiffere \\
\hline \multirow{3}{*}{$\begin{array}{l}\text { Funda } \\
\text { mental } \\
\text { s of } \\
\text { clothin } \\
\text { g }\end{array}$} & $\begin{array}{l}\text { Attractive design and } \\
\text { fashinable }\end{array}$ & $55.1 \%$ & $43.6 \%$ & $1.3 \%$ \\
\hline & Beautiful color & $67.3 \%$ & $33.7 \%$ & \\
\hline & $\begin{array}{l}\text { Good material and quality, } \\
\text { comfortable feel }\end{array}$ & $73.9 \%$ & $22.1 \%$ & $4 \%$ \\
\hline \multirow[t]{2}{*}{ quality } & Elaborate producing & $50.9 \%$ & $47.1 \%$ & $3 \%$ \\
\hline & $\begin{array}{l}\text { Easily washable and } \\
\text { durable }\end{array}$ & $65.5 \%$ & $34.5 \%$ & \\
\hline \multirow[t]{2}{*}{$\begin{array}{c}\text { functio } \\
n\end{array}$} & $\begin{array}{l}\text { Powerful function and } \\
\text { qualifying for health claims }\end{array}$ & $76.7 \%$ & $23.3 \%$ & \\
\hline & $\begin{array}{l}\text { Easy to wear and suiting } \\
\text { pathological requirements }\end{array}$ & $72.7 \%$ & $27.3 \%$ & \\
\hline service & Good after-sale service & $43.2 \%$ & $50.4 \%$ & $6.4 \%$ \\
\hline price & $\begin{array}{l}\text { Reasonable price within } \\
\text { consumption ability }\end{array}$ & $70.4 \%$ & $36.1 \%$ & $3.5 \%$ \\
\hline brand & Big brand, guaranteed & $47.3 \%$ & $30.6 \%$ & $22.1 \%$ \\
\hline
\end{tabular}

This finding shows, in various factors that influence elderly people's buying functional clothing, the most important one is the quality and function of the clothing and the acceptance degree for function factor reaches over $70 \%$. Most of the elderly are rationale consumers and their common selection is cheap, easily washable and durable clothes. However, it is also discovered that high price products with good quality are also acceptable. 


\section{The status quo of elderly people's functional clothing market}

In the European and US developed countries, elderly people's consumption market is quite developed and the market size has formed. For products like food, clothing, housing, transport and other basic necessities of life, there is mature and systemic business management pattern from research and development, production to branding operation. But the elderly people's consumption market in our country is quite desolate. Compared with the commodity in young people and middle-aged people's market, the products in elderly people's consumption market have limited number, medium quality, bad model and laggard service. There is nearly no trace of special counter or clothing boutique for the elderly, let alone the size of elderly people's market. The only existing clothes for the elderly have single color and most of them are also quite obsolete and rustic and it is quite difficult to buy well-tailored clothes. Basically in the market are clothes for young people and the so-called "business attire" for middle-aged people. When inputting "middle-aged women clothing" in the currently most representative network sale platform - Taobao, you can find only 528 shops. There is no special "middle-aged men clothing" and only several shops selling men clothes give the propagandist sign "the elderly could wear" and "functional clothing for the elderly" is nowhere to be found.

Currently, there is nearly no specialized functional clothing in the market for the elderly and only protective accessories (e.g. waist protector, knee protector, elbow protector, wrist protector, neck protector and so on), which are mainly made from wool and bamboo carbon fiber and other materials, can be found in the market. For some knee protector, magnet therapy is added. However, such knee protector is poor in convenience and function and also easily damaged after washing. Meanwhile, because of thickness, it can only be put on in autumn and winter and has no much utility. Also, there is no well-known brand for such product and the product quality can't be guaranteed. .

\section{Measures for developing the consumption potential of Chinese elderly people's functional clothing}

Forming complete policy-industry-school-research joint system for elderly people's functional clothing

The market cannot develop well without the combination of policy guidance, scientific achievements, industrial foundation and personnel training. Government, enterprise and school should be the three main parts in the development of Chinese elderly people's functional clothing and they need to jointly study around "the elderly" to realize the function of concept innovation, technological innovation, personnel training, social service, industrial development and so on. In terms of policy, government should support the research and production of elderly people's clothing market and guide numerous private enterprises to develop towards market vacancy; the enterprise must study the operation of elderly people's functional clothing brand market and carry out marketing on the basis of elderly people's consumption characteristic to gain market recognition; school should realize better social service through the transformation of scientific achievements and cultivate personnel for elderly people's dress designing and break single cultivation model of designing personnel to realize multi-dimensional design and provide service for the multiple development of designing market.

Developing the existing market according to the consuming habits of the elderly

We should analyze the information channel source of contemporary elderly people and position the corresponding functional clothing product in market segment according to the consuming habits of the elderly and propagate the concept of elderly people's functional clothing to the target consumers (including the elderly and their children) through the existing media and marketing channel. It is also necessary to make marketing strategy in view of elderly consumers psychology like "attractive appearance", "low price", "powerful function" , "good quality" and mainly highlight the effectiveness and intellectualization of functional clothing and rapidly develop 
the existing elderly market.

Paying attention to the consuming behavior of middle-aged people and cultivating potential market

Middle-aged people from 60 to 80 years old will be the consumption subject in elderly people's clothing market in 10 years, so it is very necessary to study their consumption concept within the ten years of clothing brand cultivation market. In the article "The investigation and study of consumption concept and clothing behavior of middle-aged people", the researcher finds that the mainstream consumers is "rationale consumers", accounting for $42 \%$ of the people surveyed. They are fastidious about their living quality and like buying health care products. They hold that products should offer good value for money and deny the viewpoint that "material comes first". "Prudent consumers" account for 30\% of the people surveyed. This kind of consumer group pays great attention to the cost performance of the products and they are keen on buying the health care products, antique, books and other economic goods. "Enjoying type consumers" account for 23\% of the people surveyed and they try to pay more attention to amenity of life and consumption grade and they are less influenced by traditional consumption concept. "Vanguard consumers", with the least number, account for $5 \%$ of the people surveyed and act as the pioneers of the army of consumers. They lay much emphasis on style rather than price and enjoy the sense of joy in consumption and reject the old traditional consumption concept.

\section{Conclusion}

The consumption concept of middle-aged people is significantly different from that of the elderly since the elderly lay stress on health and living quality, which are also the key points of functional clothing design. Therefore, the middle-aged people are more likely to accept this kind of product and market promotion is easier and the potential for future market will be huge.

\section{Reference}

[1] Lu Rumin, GongQuan, Zhao Ruifang. Analysis of the consumption structure of urban elderly [J]. Journal of Changchun Education Institute. 2014(7):21-27

[2]YeHongwei, Wu Ying, Guo Lihong. An investigation of Wuhan elderly people's clothing consumption and its countermeasure study [J]. Modern business industry. 2014(17):123-129.

[3] ZhuDahui. The designing feature and development trend of middle-aged and old-aged people's functional clothing [J]. The study of 2014 fashionable clothing of middle-aged and old-aged people, 2014(09):89-95

[4] Zhang Li, Liu Guolian. The investigation and study of conception concept and clothing behavior of middle-aged people [J]. Suzhou University journal. 2002(12):176-180.

[5] Yun Jinlong. Study on the relationship between universality and individuality in costume design [J]. Jiangsu Silk.2006(04):21-27 